KIRJALLISUUTTA

\title{
Tiede, politiikka ja media
}

\author{
Maria Forsman
}

https://orcid.org/0000-0001-9601-9117

Arvio teoksesta Kari Raivio: Näytön paikka: Tutkimustiedon käyttö ja väärinkäyttö. Gaudeamus, 2019. $285 \mathrm{~s}$.

Asiasanat: sivistys, tiedepolitiikka, politiikka, tieteet (erikoisalat), arvostus, tutkimustieto, tieteellinen tieto

Olen usein ihaillut sitä, että monilla lääketieteen edustajilla on taito pukea sanoiksi vaikeitakin asioita ja kertoa eloisasti myös kuivista faktoista. Näiden armoitettujen joukkoon kuuluu Kari Raivio, lastenlääkäri, joka on toiminut merkittävissä asemissa suomalaisessa tieteessä ja tiedepolitiikassa - muun muassa Helsingin yliopiston rehtorina ja kanslerina - ja ottanut kantaa tieteen ja politiikan tapahtumiin.

Näytön paikka -kirjan tekemisen taustalla on Raivion mukaan huoli siitä, että päätöksenteko ja julkinen keskustelu etääntyvät viisaan ihmisen käyttäytymisestä. Onko päätöksentekijälle arvokasta vain sellainen tieto, joka tukee hänen omia käsityksiään? Joutaako romukoppaan tieto, joka aiheuttaa ristiriitoja tai josta puhuminen estää poliitikkoa pääsemästä seuraavalle kaudelle eduskuntaan? Siksi Raivio Artikkeli on lisensoitu Creative Commons Nimeä-EiKaupallinen-JaaSamoin 4.o Kansainvälinen -lisenssillä Pysyvä osoite: https://doi.org/10.23978/inf. 86970 
haluaa "edes yrittää osoittaa, että tutkitulla tiedolla voi olla ratkaiseva merkitys yhteiskunnan kehittämisessä".

Omat lukunsa kirjassa saavat näyttöön perustuva lääketiede, näyttö oikeussalissa ja ilmastonmuutokseen liittyvä keskustelu. Näistä erityisen kiinnostavaa oli lukea ilmastonmuutosta käsittelevää lukua, jossa on taitavasti yhdistetty ympäristöheräämisen historiaa, tutkimustietoa ja meidän aikamme keskustelua.

Kirjasta välittyy useasta kohtaa Raivion harmitus erityisesti vuosina 2015-2019 toiminutta Juha Sipilän hallitusta ja sen monien ministerien sivistymättömyyttä kohtaan. Joidenkin ministerien poukkoileva, olemattomaan tietoon perustuva päätöksenteko on suututtanut häntä. Raivio ei selvästikään pidä tyhmistä ihmisistä päättäjän paikalla.

Raivio ei ole ennenkään ollut vaiti, kun on ollut tarvetta ottaa kantaa. Esimerkiksi Helsingin yliopiston avajaisissa vuonna 1999 Raivio piti rehtorin asemassa puheen, jossa hän arvosteli suoraan silloista opetusministeriä Maija Raskia ja opetusministeriötä. Hän koki, että Paavo Lipposen hallitus ei arvosta tutkijankoulutusta ministerien valinnassa, vaan puolueen lisäksi asuinpaikka ja sukupuoli ratkaisevat.

Raivio sai puheestaan nuhteita ministeriöstä yliopiston kanslerin kautta, mitä hän edelleen ihmettelee: "Ajatus, jonka mukaan autonomisen yliopiston rehtorilla ei olisi oikeutta, jopa velvollisuutta, kritisoida aiheen ilmaantuessa vallanpitäjiä, mukaan lukien 'oma' ministeriö, tuntui minusta silloin käsittämättömältä, ja tuntuu edelleen."

Osansa Raivion kritiikistä saavat myös iltapäivälehtien hämäävät ja hämärät otsikot ja nettilehtien klikkausjournalismi. Erityisesti terveyttä koskeva uutisointi, josta me maallikot olemme ymmärrettävästi kiinnostuneita, suututtaa lääketieteilijää pinnallisuudellaan ja sensaatiohakuisuudellaan. Raflaavat otsikot saattavat johtaa huuhaahan ja saada lukijat uskomaan harhaanjohtavaan tietoon. Toisaalta Raivio arvostaa asiansa osaavia tiedetoimittajia ja sitä, että muun muassa Yleisradio ja Helsingin Sanomat julkaisevat suurelle yleisölle tarkoitettuja tiedejuttuja. Kiitosta saavat myös Tiede-lehti ja Tieteen kuvalehti.

Raiviolla on paljon kriittistä asiaa myös omasta kentästään, tieteen ja tutkimuksen tekemisestä. Myös tieteessä voidaan sepittää, vääristellä ja varastaa, käyttää tietoa valikoiden, kun se sopii omiin tarkoituksiin, ja viis veisata siitä, jos se on ristiriidassa omien vakaumusten kanssa. 
Tieteen ja tiedepolitiikan parissa työskenneelle Näytön paikka -kirja tarjoaa paljon sekä tuttua että yllättävää asiaa.

Raivio pohtii tieteen maailmasta tuttuja vilpin muotoja. Tieteen historiasta löytyy esimerkkejä tutkijoista, jotka ovat harrastaneet tutkimustulosten sepittämistä ja vääristelyä jonkin edun toivossa; useimmiten he ovat jääneet siitä kiinni. Tekstivarkaus ja ideoiden anastaminen taas on ollut vanhempien tutkijoiden pahe suhteessa nuorempiin tutkijoihin. Se on vähän niin kuin "\#metoo-ilmiö" - asiaan ei ole uskallettu tai haluttu tiedeyhteisössä puuttua, ettei oma ura tyssäisi siihen.

Toisaalta Raivio antaa esimerkkejä tutkijoista, jotka ovat olleet aikaansa edellä. Tutkija on löytänyt jotain sellaista, joka ei ole aiemmin tunnettua tai joka järisyttää vakiintunutta maailmankuvaa, ja niin hän on saattanut joutua pilkan ja väheksynnän kohteeksi. Ehkä vasta vuosien tai vuosisatojen kuluttua joku toinen tutkija on paremmilla menetelmillä ja laitteilla kyennyt osoittamaan aiemmat tulokset ja havainnot oikeiksi. Näin on voitu palauttaa väheksytyn tutkijan menetetty maine - tosin tutkija ei usein itse enää ole sitä kuulemassa.

Raivio osaa taitavasti luoda kriittisiä katseita asioihin, joista me kaikki ajattelemme tietävämme jotain ja joista meillä on omat mielipiteemme. Uskomattomiltakin tuntuvat esimerkit ovat selvästi tarkistettua faktaa. Kirjoitustyyli liikkuu tyylikkäästi asiatekstin ja kevyen sanailun välillä.

Hauska ja kätevä ratkaisu on ollut konkreettisten esimerkkien pakkaaminen "tiedonjyvälaatikoihin"; näin ne eivät katkaise sujuvaa perustekstiä. Laatikoille on annettu lukemaan houkuttelevia otsikoita, esimerkiksi: "Päähänpistot, nyrkkisäännöt ja ajattelun vaikeus", "Älyn välähdys - Heureka!", "Pärstäkerroin ratkaisee - jo lapsuudessa", "Ajatuspajat", "Lumekirurgia", "Lisbet Palme - epäluotettava silminnäkijä?”.

Näytön paikka on siis nautittavaa luettavaa tiedettä, tiedepolitiikkaa ja yhteiskunnallista keskustelua seuraavalle.

Maria Forsman ${ }^{1}$

Valtiotieteen tohtori

Helsinki

1 Toim. huom.: VTT Maria Forsman valittiin vuoden tieteentekijäksi 2013. Ks. lisätietoja Tieteentekijöiden liitto, Vuoden tieteentekijä - johtava tietoasiantuntija Maria Forsman, https://tieteentekijoidenliitto.fi/media/tiedotteet/tiedotteet_2013/vuoden_ tieteentekija_-_johtava_tietoasiantuntija_maria_forsman.28.news 